\title{
Pengaruh Silase Sinambung Jerami Jagung Terhadap Fermentasi Dalam Cairan Rumen Secara In Vitro
}

\author{
C. E. Kusumaningrum ${ }^{1 a}$, I. Sugoro ${ }^{1}$ dan P. Aditiawati ${ }^{2}$ \\ ${ }^{I}$ Pusat Aplikasi Isotop dan Radiasi, Badan Tenaga Nuklir Nasional \\ ${ }^{2}$ Sekolah Ilmu dan Teknologi Hayati, Institut Teknologi Bandung \\ aemail: yohanaellen86@gmail.com
}

\begin{abstract}
Abstrak
Penelitian dilakukan untuk mengevaluasi pengaruh penggunaan silase sinambung jerami jagung terhadap, nilai $\mathrm{pH}$, volatile fatty acid (VFA), amonia $\left(\mathrm{NH}_{3}\right)$, produksi gas total dan produksi biomassa mikroba sebagai pakan ternak ruminansia secara in vitro. Rancangan percobaan dalam penelitian ini adalah Rancangan Acak Lengkap Pola Faktorial 3x6 dengan 3 ulangan. Faktor pertama dalam rancangan penelitian ini adalah pakan perlakuan yaitu pakan kontrol (P1), jerami jagung (P2) dan silase sinambung jerami jagung (P3) dan faktor kedua adalah waktu inkubasi selama fermentasi in vitro yaitu 0, 2, 4, 6, 12 dan 24 jam (T1, T2, T3, T4, T5 dan T6). Hasil penelitian menunjukkan bahwa baik pakan perlakuan maupun waktu inkubasi tidak memberikan pengaruh yang nyata $(p>0,05)$ terhadap nilai $\mathrm{pH}, \mathrm{VFA}, \mathrm{NH}_{3}$, produksi gas total dan produksi biomassa mikroba serta tidak terdapat interaksi antara perlakuan pakan dengan waktu inkubasi. Secara numerik, kisaran pH perlakuan adalah 6,89 - 7,05; konsentrasi VFA sebesar 107-110 mM, konsentrasi amonia 23,92 - 29,88 mg/100 $\mathrm{ml}$, produksi gas total sebesar 27,47 - 46,31 ml/200 mg dan produksi biomassa mikroba sebesar 40,60 - 56,80 mg/20 ml. Kesimpulan pada penelitian ini adalah baik jerami jagung maupun silase sinambung jerami jagung dapat digunakan sebagai pakan ternak karena mampu memenuhi kebutuhan nutrisi ternak ruminansia ditinjau dari produksi gas dan fermentasi pakan dalam rumen.
\end{abstract}

Kata kunci: silase sinambung jerami jagung, amonia, VFA, produksi gas in vitro.

\section{Effect of Corn Straw Silage to Rumen Fermentation by In Vitro Method}

\begin{abstract}
The aim of this study was to evaluate the effect of corn straw silage at $p H$ value, volatile fatty acid (VFA), ammonia (NH3), total gas production and microbial biomass production as ruminants feed by in vitro method. The experimental design in this study was Factorial Completely Randomized Design $3 x 6$ with 3 replications. The first factor in the design of this study was feed treatment, they are control feed (P1), corn straw (P2) and silage continuous corn straw (P3) and the second factor was incubation time during in vitro fermentation, 0, 2, 4, 6, 12 and 24 hours (T1, T2, T3, T4, T5 and T6). The results showed that neither feed treatment nor incubation time gave significant effect $(p>0,05)$ to $\mathrm{pH}$ value, VFA, $\mathrm{NH}_{3}$, total gas production and microbial biomass production and no interaction between feed treatment and incubation time. Numerically, the treatment pH range was $6.89-7.05$; $V F A$ concentrations range was 107-110 mM, ammonia concentrations range was $23.92-29.88 \mathrm{mg}$ / $100 \mathrm{ml}$, total gas production range was $27.47-46.31 \mathrm{ml} / 200 \mathrm{mg}$ and microbial biomass production range was 40.60 - $56.80 \mathrm{mg} / 20 \mathrm{ml}$. Conclusion in this research is both corn straw and corn straw silage can be used as animal feed because able to fulfill requirement of ruminant livestock nutrition in terms of gas production and fermentation of feed in rumen.
\end{abstract}

Keywords: Corn Straw Silage, amonia, VFA, in vitro gas production. 


\section{Pendahuluan}

Pakan merupakan salah satu faktor yang berpengaruh terhadap produktivitas ternak ruminansia. Untuk memperoleh produktivitas yang baik diperlukan pakan yang mempunyai kualitas, kuantitas dan ketersediaan yang baik pula (Delima et al., 2015). Namun kendala yang dihadapi adalah ketersediaan pakan yang relatif rendah pada saat musim kemarau dan penurunan kualitas pakan seperti rendahnya nilai kecernaan pakan serta kandungan nutrient. Pakan dengan nilai kecernaan yang rendah mengakibatkan degradasi pakan rendah sehingga tidak mampu mengimbangi aktivitas fermentasi pakan oleh mikroba rumen. Hal ini menyebabkan rendahnya pertumbuhan mikroba di dalam rumen dan rendahnya konsumsi pakan, sehingga produktivitas ternak mengalami penurunan (Yanuarianto et al., 2015).

Limbah pertanian merupakan pakan yang dapat dimanfaatkan untuk ternak ruminansia. Salah satu limbah pertanian yang sering digunakan sebagai pakan adalah jerami jagung. Namun jerami jagung mempunyai kandungan serat kasar yang tinggi, sehingga akan membatasi pemanfaatannya oleh ternak (Pertiwi et al, 2015). Untuk mengatasi masalah tersebut salah satunya dilakukan proses pembuatan silase, yaitu proses fermentasi jerami jagung yang memanfaatkan mikroba sehingga dapat memudahkan pendegradasian serat serta meningkatkan daya cerna. Silase jerami jagung diharapkan dapat disimpan tanpa mengurangi kualitas dan nilai kandungan nutrisinya sehingga dapat dimanfaatkan pada masa mendatang (Titterton dan Bareeba, 2008).

Pada pembuatan silase, untuk mempercepat pembentukan asam laktat dan asetat guna mencegah terbentuknya fermentasi yang tidak dikehendaki, serta merupakan suplemen untuk zat gizi dalam pakan perlu adanya penambahan bibit silase (Rukana, 2014). Salah satu bibit yang dapat digunakan adalah silase itu sendiri, yaitu dengan memanfaatkan silase yang sudah jadi sebagai bibit pembuatan silase berikutnya, teknik ini juga dapat disebut dengan teknologi silase sinambung. Keunggulan teknik silase sinambung adalah waktu fermentasi yang terjadi dapat dilakukan dengan singkat dibandingkan dengan teknik silase pada umumnya yang di atas 21 hari (Sugoro, 2010).
Pengolahan limbah pertanian tanaman pakan dengan teknologi silase banyak dilakukan karena mudah dalam aplikasinya, murah, hasilnya memuaskan dan kandungan nutrien yang lebih baik. Silase memiliki kadar air antara 60-70 \% dan mengandung asam laktat yang tinggi. Asam laktat dihasilkan oleh Bakteri Asam Laktat (BAL) sehingga tingkat pembusukkan dapat diminimalisir. Prinsip pembuatan silase adalah fermentasi oleh mikroba yang banyak menghasilkan asam laktat yang mampu melakukan fermentasi dalam keadaan aerob sampai anaerob. Asam laktat yang dihasilkan selama proses fermentasi akan berperan sebagai zat pengawet sehingga dapat menghindarkan pertumbuhan mikroorganisme pembusuk (Pratiwi et al., 2015).

Berdasarkan uraian di atas maka tujuan dari penelitian ini adalah untuk mengevaluasi pengaruh penggunaan silase jerami jagung sebagai pakan ternak ruminansia terhadap produksi gas dan metabolisme rumen. Peubah yang diamati adalah produksi gas total yang dihasilkan, fermentasi pakan dalam rumen ( $\mathrm{pH}$, VFA, amonia) dan produksi biomassa mikroba rumen.

\section{Materi dan Metode Alat dan Bahan}

Alat-alat yang digunakan adalah alatalat gelas, $\mathrm{pH}$ meter, timbangan, desikator, oven, tanur, cawan porselen, sentrifus cawan Conway, syringe, buret, water bath shaker dan destilator. Bahan-bahan utama yang digunakan adalah cairan rumen, jerami jagung giling, serbuk bibit silase jerami jagung untuk bibit silase sinambung, silase sinambung jerami jagung dan larutan Mc Dougall serta cairan rumen sapi.

\section{Pembuatan Silase Jerami Jagung}

Tanaman jagung yang telah dipanen buah, diambil jeraminya kemudian dilayukan selama 24 jam selanjutnya dicacah menggunakan chopper menjadi ukuran 5-10 $\mathrm{cm}$. Bagian batang dan daun jerami jagung yang telah dicacah, dicampur hingga homogen. Sebanyak $1 \mathrm{~kg}$ jerami jagung dimasukkan ke dalam plastik (silo) kemudian diberi perlakuan sesuai dengan pakan perlakuan penelitian ini yaitu pakan kontrol (P1), jerami jagung (P2) dan silase sinambung jerami jagung (P3). Kemudian dicampur sampai homogen dan diikat rapat 
menggunakan karet untuk mempertahankan kondisi silo anaerob. Silase diinkubasi selama 21 hari, kemudian dipanen dan dikeringkan sehingga menjadi serbuk, untuk selanjutnya digunakan sebagai bahan analisis produksi gas.

\section{Uji In Vitro}

Metode produksi gas dilakukan sesuai dengan petunjuk Menke dan Steingass (1998). Perlakuan terdiri atas cairan rumen yang ditambahkan serbuk jerami jagung dan serbuk silase sinambung jerami jagung dengan ulangan 3 kali. Data dianalisis dengan menggunakan Rancangan Acak Lengkap (RAL) Pola Faktorial 3x6 dengan 3 ulangan. Faktor pertama dalam rancangan penelitian ini adalah pakan perlakuan yaitu pakan kontrol (P1), jerami jagung (P2) dan silase sinambung jerami jagung (P3) dan faktor kedua adalah waktu inkubasi selama fermentasi in vitro yaitu 0, 2, 4, 6, 12 dan 24 jam (T1, T2, T3, T4, T5 dan T6). Sampel pakan perlakuan ditimbang $200 \mathrm{mg}$ BK, dimasukkan didasar syringe glass dan diusahakan jangan menempel pada dinding syringe. Sedangkan piston sebelum dimasukkan ke dalam syringe terlebih dahulu dilumuri dengan vaselin. Kemudian disiapkan campuran bufer dan mineral (tanpa larutan reduksi) yaitu $1095 \mathrm{ml}$ akuades, $730 \mathrm{ml}$ larutan bufer, $365 \mathrm{ml}$ makromineral, 0,23 mikromineral, $1,0 \mathrm{ml}$ resazurin diletakkan dalam waterbath suhu $39^{\circ} \mathrm{C}$ sambil dialiri $\mathrm{CO}_{2}$ dan diaduk dengan magnetik stirer. Sebelum dicampurkan dengan cairan rumen, terlebih dahulu ditambahkan sebanyak $60 \mathrm{ml}$ larutan reduksi hingga terjadi perubahan warna dari merah muda menjadi bening yang menandakan kondisi media dalam keadaan anaerob. Cairan rumen sebanyak 660 $\mathrm{ml}$ yang telah disiapkan dicampur dengan media gas tes. Sebanyak $30 \mathrm{ml}$ dimasukkan ke dalam tiap glass syringe melalui selang silikon dengan dispenser yang telah diatur volumenya. Gelembung udara yang ada dikeluarkan, kemudian selang silikon ditutup dengan klem, posisi piston dibaca dan dicatat pada jam ke-0. Kemudian glass glass syringe ditempatkan dalam waterbath inkubator suhu $39{ }^{\circ} \mathrm{C}$. Produksi gas dibaca dan dicatat pada jam ke 0, 2, 4, 6, 12 dan 24 jam. Sampel produksi gas setelah inkubasi 24 jam masing-masing diukur nilai pH, VFA (Lutzhoft et al, 2014), amonia (Widodo et al., 2012) dan produksi biomassa mikroba rumen.

\section{Analisis Statistik}

Rancangan percobaan yang digunakan dalam penelitian adalah Rancangan Acak Lengkap (RAL) faktorial 3x6 dan 3 ulangan dengan pakan perlakuan sebagai faktor pertama dan waktu inkubasi selama fermentasi in vitro sebagai faktor kedua. Data statistik yang diperoleh selanjutnya dianalisis dengan Analysis of Variance (ANOVA).

\section{Hasil dan Pembahasan Nilai pH}

Nilai pH cairan rumen awal pada penelitian ini adalah 7,07 dan mengalami penurunan setelah inkubasi selama 24 jam baik pada jerami jagung maupun pada silase jerami jagung. Namun penurunan $\mathrm{pH}$ setelah inkubasi pada silase sinambung jerami jagung lebih banyak dibandingkan pada jerami jagung. Hal ini ditunjukkan dari rerata $\mathrm{pH}$ pada jerami jagung berkisar antara 6,93-7,05 sedangkan pada silase sinambung jerami jagung berkisar antara 6,89-7,02 (Tabel 1). Pada silase sinambung jerami jagung, nilai $\mathrm{pH}$ yang lebih rendah daripada jerami jagung disebabkan silase sinambung jerami jagung lebih mempunyai sifat asam dibandingkan dengan jerami jagung. Sifat asam pada silase sinambung jerami jagung tersebut terjadi karena adanya proses fermentasi selama proses pembuatan silase sinambung jerami jagung dimana karbohidrat mudah larut pada pakan akan dimanfaatkan oleh bakteri untuk menghasilkan asam laktat yang berperan dalam menurunkan $\mathrm{pH}$ silase secara cepat, penurunan $\mathrm{pH}$ silase tersebut merupakan energi bagi bakteri pembentuk asam laktat sehingga semakin banyak asam laktat yang diproduksi, maka semakin cepat laju penurunan $\mathrm{pH}$ (Sandi et al., 2010). Perubahan nilai $\mathrm{pH}$ rumen pada masing-masing perlakuan pada penelitian ini dapat dilihat pada Tabel 1.

Berdasarkan analisis ragam, ditunjukkan bahwa baik pakan perlakuan maupun waktu inkubasi tidak memberikan pengaruh yang nyata terhadap nilai $\mathrm{pH}$ pada cairan rumen serta tidak terdapat interaksi antara pakan perlakuan dengan waktu inkubasi ( $>0,05)$. Namun nilai $\mathrm{pH}$ berada pada kisaran nilai yang optimum untuk pertumbuhan dan aktivitas mikroba, yaitu 6,89 - 7,05. Hal ini sesuai dengan pendapat Hungate (1996) bahwa nilai $\mathrm{pH}$ optimum untuk pertumbuhan dan aktivitas mikroba rumen adalah sebesar 5,5- 
Tabel 1. Nilai pH

\begin{tabular}{|c|c|c|c|c|c|c|c|c|c|c|}
\hline \multirow{2}{*}{$\begin{array}{l}\text { Variabel } \\
\text { Nilai pH }\end{array}$} & $\begin{array}{l}\text { Pakan } \\
\text { Perlakuan }\end{array}$ & \multicolumn{6}{|c|}{ Waktu Inkubasi } & \multicolumn{3}{|c|}{ Signifikansi } \\
\hline & & $\mathrm{T} 1$ & $\mathrm{~T} 2$ & T3 & T4 & T5 & T6 & $\mathrm{P}$ & $\mathrm{T}$ & PxT \\
\hline & P1 & 6,98 & 7,00 & 6,99 & 6,96 & 7,02 & 6,96 & $\mathrm{~ns}$ & $\mathrm{~ns}$ & ns \\
\hline & P2 & 6,96 & 7,00 & 7,05 & 7,03 & 6,93 & 6,93 & & & \\
\hline & P3 & 6,93 & 6,99 & 7,02 & 7,01 & 6,93 & 6,89 & & & \\
\hline
\end{tabular}

Keterangan: P1. Pakan Kontrol, P2. Jerami Jagung, P3. Silase Sinambung Jerami Jagung, T1. 0 Jam, T2. 2 Jam, T3. 4 Jam, T4. 6 Jam, T5. 12 Jam, T6. 24 Jam.

7,3. Tinggi rendahnya nilai $\mathrm{pH}$ akan sangat mempengaruhi aktivitas dan pertumbuhan mikroba rumen sehingga akan mempengaruhi berlangsungnya proses fermentasi di dalam rumen (Van Soest, 1994).

\section{Produksi VFA}

VFA (terdiri dari asetat, propionat dan butirat) merupakan produk utama dari fermentasi mikrobial karbohidrat dalam rumen. VFA yang diproduksi dalam sistem pencernaan rumen dapat dimanfaatkan langsung oleh ternak untuk membangun dinding selnya. Laktat juga dapat diserap langsung melalui rumen dan retikulum untuk dimanfaatkan ternak sebagai sumber energi (Nopitasari et al., 2013). Pengaruh perlakuan terhadap produksi VFA tertera pada Tabel 2.

Hasil analisis ragam menunjukkan bahwa baik pakan perlakuan maupun waktu inkubasi serta interaksi antara pakan perlakuan dan waktu inkubasi yang diberikan berpengaruh tidak nyata $(p>0,05)$. Namun, secara numerik rataan produksi VFA perlakuan berkisar antara $107-110 \mathrm{mM}$, nilai tersebut sudah memenuhi nilai kecukupan VFA. Pada silase jerami jagung produksi VFA yang dihasilkan yaitu sebesar $109 \pm 0,80 \mathrm{mM}$, mempunyai nilai rataan yang relatif sama dengan jerami jagung yaitu sebesar $108 \pm 1,22$ $\mathrm{mM}$. Produksi VFA yang tidak berpengaruh nyata diduga bahwa proses fermentasi pada silase jerami jagung tidak mengubah struktur serat kasar, sehingga produksi VFA yang dihasilkan relatif sama dengan jerami jagung tanpa fermentasi (Nopitasari, 2013). Hal ini ditunjukkan dari kandungan serat kasar pada silase jerami jagung yang relatif sama dengan jerami jagung, dimana kandungan serat kasar pada silase jerami jagung sebesar 24,01\% sedangkan jerami jagung sebesar 29,34\%. Nilai VFA menunjukkan terjadinya fermentasi senyawa kompleks yakni karbohidrat serat kasar) menjadi VFA. Komponen serat kasar bermacam-macam salah satunya yakni selulosa. Selulosa akan didegradasi oleh enzim selulase untuk menghasilkan selobiosa yang nantinya akan dipecah menjadi gula-gula sederhana. Gula-gula sederhana ini akan mengalami proses glikolisis menjadi asam piruvat melalui oksidasi glukosa secara anaerob. Asam piruvat kemudian diubah menjadi VFA berupa asetat, propionat dan butirat. Selain itu juga menghasilkan $\mathrm{H}_{2} \mathrm{O}$, $\mathrm{CO}_{2}$ dan $\mathrm{CH}_{4}$. VFA nantinya akan diserap oleh dinding rumen yang digunakan sebagai sumber karbon (Krishnamoorthy, 2001) dalam (Imanda et al., 2016).

\section{Produksi Amonia}

Sutardi (2006), menyatakan bahwa sebagian protein yang masuk ke dalam rumen akan mengalami perombakan oleh enzim proteolitik yang dihasilkan oleh mikroba rumen menjadi amonia.

Tabel 2. Konsentrasi VFA

\begin{tabular}{lccccccccccc}
\hline Variabel & $\begin{array}{l}\text { Pakan } \\
\text { Perlakuan }\end{array}$ & \multicolumn{3}{l}{ Waktu Inkubasi } & & & & \multicolumn{3}{c}{ Signifikansi } \\
\cline { 1 - 11 } Nilai & & T1 & T2 & T3 & T4 & T5 & T6 & P & T & PxT \\
VFA & & & & & & & & & & \\
\hline & P1 & 108 & 107 & 107 & 110 & 109 & 111 & ns & ns & ns \\
& P2 & 108 & 110 & 107 & 109 & 107 & 109 & & & \\
& P3 & 109 & 110 & 108 & 108 & 109 & 109 & & & \\
\hline
\end{tabular}

Keterangan: P1. Pakan Kontrol, P2. Jerami Jagung, P3. Silase Sinambung Jerami Jagung, T1. 0 Jam, T2. 2 Jam, T3. 4 Jam, T4. 6 Jam, T5. 12 Jam, T6. 24 Jam. 
Amonia merupakan sumber nitrogen utama bagi mikroba rumen karena amonia yang dibebaskan dalam rumen sebagian dimanfaatkan oleh mikroba untuk sintesis protein mikroba (Nuswantara, 2002). Mikroba rumen akan memanfaatkan amonia sebagai sumber nitrogen terbesar yang digunakan dalam sintesis protein. Protein yang dihasilkan dapat berperan sebagai protein struktural dalam pembentukan komponen sel dan fungsional dalam bentuk enzim (McDonald et al, 2002).

Rataan konsentrasi amonia perlakuan yang dihasilkan berkisar antara 23,92 - 29,88 $\mathrm{mg} / 100 \mathrm{ml}$. Nilai tersebut sudah dapat mendukung pertumbuhan mikroba rumen. Sebagaimana terdapat dalam Satter dan Slyter (1974) yang menyebutkan bahwa kisaran normal konsentrasi amonia untuk pertumbuhan mikroba rumen dan sintesis protein mikroba adalah $20-40 \mathrm{mg} / 100 \mathrm{ml}$ cairan rumen. Pengaruh perlakuan terhadap produksi amonia tertera pada Tabel 3.

Hasil analisis ragam menunjukkan tidak terdapat pengaruh yang nyata $(\mathrm{P}>0,05)$ baik pada pakan perlakuan maupun waktu inkubasi serta interaksi antara pakan perlakuan dan waktu inkubasi terhadap produksi amonia. Nilai rataan produksi amonia pada jerami jagung dan silase sinambung jerami jagung relatif sama. Pada silase sinambung jerami jagung yaitu sebesar 27,75 $\pm 2,08 \mathrm{mg} / 100 \mathrm{ml}$, sedangkan pada jerami jagung sebesar 27,37 \pm $2,27 \mathrm{mg} / 100 \mathrm{ml}$. Hal tersebut menunjukkan bahwa baik perlakuan jerami jagung maupun silase sinambung jerami jagung tidak mempengaruhi produksi amonia. Hal ini disebabkan karena salah satu faktor yang menyebabkan tinggi rendahnya produksi amonia, yaitu kandungan protein kasar, baik pada silase sinambung jerami jagung maupun jerami jagung relatif sama yaitu sebesar $10,64 \%$ dan $9,94 \%$. Hal ini sesuai dengan pendapat Hindratiningrum (2011) yang menyatakan bahwa faktor yang mempengaruhi tinggi rendahnya produksi amonia adalah sumber protein dalam pakan yang mudah terdegradasi oleh mikroba rumen. Protein pakan yang masuk ke dalam rumen sebagian diuraikan oleh mikroba menjadi asam-asam amino dan kemudian dideaminasi untuk membentuk asam-asam organik, amonia, $\mathrm{CO}_{2}$ dan sebagian lagi tidak mengalami degradasi. Selanjutnya sebagian dari ammonia yang terbentuk di dalam rumen tersebut dikombinasikan dalam asam-asam alfa keto dari sumber-sumber protein atau karbohidrat digunakan untuk mensintesa asamasam amino baru untuk pembentukan protein mikroba (Arora, 1995 dalam Saqifah et al., 2010).

\section{Produksi Gas Total}

Produksi gas merupakan indikasi adanya aktivitas metabolisme mikroba di dalam rumen yang mampu menggambarkan proses fermentasi substrat pakan menjadi produk berupa VFA dan biomassa mikroba rumen (Blummel dan Orskov, 1993). Gas yang dihasilkan merupakan hasil fermentasi pakan, terutama bahan organik menjadi VFA yang dilakukan oleh mikroba rumen. Gas yang terbentuk adalah $\mathrm{CO}_{2} 64 \%, \mathrm{CH}_{4} 25-27 \%, \mathrm{~N}$ $27 \%$ dan sedikit $\mathrm{O}_{2}, \mathrm{H}_{2}$, dan $\mathrm{H}_{2} \mathrm{~S}$. Jumlah gas yang diproduksi menunjukkan tinggi rendahnya kecernaan pakan. Produksi gas yang terlalu tinggi menunjukkan ketidakefisienan pemakaian pakan sehingga menimbulkan kembung dan meningkatkan gas rumah kaca. Jumlah gas yang sedikit menunjukkan bahwa bahan organik terfermentasi digunakan untuk sintesis protein mikroba (Van Soest, 1994). Pola peubah produksi gas berkaitan erat dengan pengaruh pertumbuhan mikroba yang ada di dalam cairan rumen. Produksi gas untuk masingmasing pakan perlakuan pada waktu inkubasi 0, 2, 4, 6, 12 dan 24 ditunjukkan pada Tabel 4 .

Tabel 3. Produksi Amonia

\begin{tabular}{|c|c|c|c|c|c|c|c|c|c|c|}
\hline \multirow{2}{*}{$\begin{array}{l}\text { Variabel } \\
\text { Nilai pH }\end{array}$} & \multirow{2}{*}{$\begin{array}{l}\text { Pakan } \\
\text { Perlakuan }\end{array}$} & \multicolumn{6}{|c|}{ Waktu Inkubasi } & \multicolumn{3}{|c|}{ Signifikansi } \\
\hline & & T1 & $\mathrm{T} 2$ & T3 & T4 & T5 & T6 & $P$ & $\mathrm{~T}$ & PxT \\
\hline & P1 & 31,18 & 24,71 & 28,04 & 27,46 & 25,34 & 27,41 & $\mathrm{~ns}$ & $\mathrm{~ns}$ & $\mathrm{~ns}$ \\
\hline & P2 & 29,88 & 26,18 & 28,67 & 29,21 & 23,92 & 26,35 & & & \\
\hline & $\mathrm{P} 3$ & 28,67 & 28,01 & 29,72 & 29,31 & 24,09 & 26,71 & & & \\
\hline
\end{tabular}

Keterangan: P1. Pakan Kontrol, P2. Jerami Jagung, P3. Silase Sinambung Jerami Jagung, T1. 0 Jam, T2. 2 Jam, T3. 4 Jam, T4. 6 Jam, T5. 12 Jam, T6. 24 Jam. 
Tabel 4. Produksi Gas Total

\begin{tabular}{llllllllllll}
\hline Variabel & $\begin{array}{l}\text { Pakan } \\
\text { Perlakuan }\end{array}$ & \multicolumn{3}{l}{ Waktu Inkubasi } & & & & & & \multicolumn{3}{c}{ Signifikansi } \\
\hline $\begin{array}{l}\text { Nilai } \\
\text { Produksi }\end{array}$ & & T1 & T2 & T3 & T4 & T5 & T6 & P & T & PxT \\
Gas & & & & & & & & & & \\
\hline & P1 & 27,47 & 28,47 & 28,93 & 28,84 & 28,67 & 28,88 & ns & ns & ns \\
& P2 & 28,37 & 32,10 & 34,11 & 35,02 & 37,70 & 46,31 & & & \\
& P3 & 28,16 & 30,93 & 32,20 & 32,88 & 34,63 & 45,26 & & & \\
\hline
\end{tabular}

Keterangan: P1. Pakan Kontrol, P2. Jerami Jagung, P3. Silase Sinambung Jerami Jagung, T1. 0 Jam, T2. 2 Jam, T3. 4 Jam, T4. 6 Jam, T5. 12 Jam, T6. 24 Jam

Pada Tabel 4 ditunjukkan bahwa nilai produksi gas jerami jagung pada setiap jam perlakuan lebih tinggi dibandingkan pada silase jerami jagung. Jumlah gas yang lebih sedikit pada silase sinambung jerami jagung kemungkinan disebabkan karena telah terpakainya bahan organik terfermentasi untuk sintesis mikroba (Orskov dan Ryle, 1990). Sedangkan pada jerami jagung kemungkinan kandungan nutrisi pakan masih tersedia sehingga mengakibatkan aktivitas mikroba masih optimum dalam mendegradasi pakan sehingga produksi gas masih optimum juga.

Volume gas pada awal inkubasi pada jam ke- 0, 2, 4, 6 dan 12 mengalami peningkatan sedikit demi sedikit, sedangkan pada jam ke-24 menunjukkan adanya peningkatan volume gas yang lebih tinggi yang dikarenakan adanya pertumbuhan dan aktivitas mikroba dalam proses fermentasi. Apabila ditinjau berdasarkan fase pertumbuhan mikroba, maka pada jam inkubasi ke- 0, 2, 4, 6 dan 12 mikroba mengalami fase adaptasi atau fase lag. Pada fase lag, mikroba akan mengalami penyesuaian terhadap lingkungannya dan belum maksimal dalam memanfaatkan substrat yang tersedia. Selanjutnya pada jam ke-24, volume gas mengalami kenaikan yang cukup tinggi. Hal ini kemungkinan disebabkan karena mikroba sedang mengalami fase logaritmik (fase log). Dimana pada fase ini terjadi pertumbuhan dan perkembangbiakan mikroba yang sangat cepat serta proses metabolisme dan pembelahan sel yang berjalan dengan maksimal. Pada fase inilah mikroba mulai mendegradasi pakan, merombak karbohidrat menjadi struktur yang lebih sederhana dan menghasilkan gas dari perombakan bahan organik. Selama proses inkubasi berlangsung maka pakan yang ada dalam cairan rumen dan buffer secara in vitro akan difermentasi menjadi VFA, gas $\mathrm{CO}_{2}$ dan metana serta terjadi proses sintesis mikroba (Krishnamoorthy, 2001).

\section{Produksi biomassa mikroba rumen}

Biomassa mikroba menandakan banyaknya jumlah mikroba yang terdapat di dalam cairan rumen, dimana mikroba tersebut berperan dalam metabolisme rumen yaitu proses fermentasi rumen dan kecernaan pakan. Hasil produksi biomassa mikroba rumen pada penelitian ditunjukkan pada Tabel 5 .

Hasil analisa ragam menunjukkan bahwa baik pakan perlakuan, waktu inkubasi dan interaksi antara pakan perlakuan dan waktu inkubasi memberikan perbedaan yang tidak nyata terhadap biomassa mikroba rumen $(\mathrm{p}>0,05)$.

Tabel 5. Produksi Biomassa Mikroba Rumen

\begin{tabular}{lllllllllll}
\hline Variabel & $\begin{array}{l}\text { Pakan } \\
\text { Perlakuan }\end{array}$ & \multicolumn{3}{l}{ Waktu Inkubasi } & & & & & & \multicolumn{3}{c}{ Signifikansi } \\
\hline $\begin{array}{l}\text { Nilai } \\
\text { Produksi }\end{array}$ & & T1 & T2 & T3 & T4 & T5 & T6 & P & T & PxT \\
Gas & & & & & & & & & & \\
\hline & P1 & 40,60 & 48,43 & 46,37 & 43,00 & 47,77 & 44,97 & ns & ns & ns \\
& P2 & 49,53 & 49,43 & 47,63 & 48,67 & 54,77 & 52,47 & & & \\
& P3 & 51,00 & 48,23 & 47,40 & 51,43 & 54,77 & 56,80 & & & \\
\hline
\end{tabular}

Keterangan: P1. Pakan Kontrol, P2. Jerami Jagung, P3. Silase Sinambung Jerami Jagung, T1. 0 Jam, T2. 2 Jam, T3. 4 Jam, T4. 6 Jam, T5. 12 Jam, T6. 24 Jam 
Hal ini menunjukkan bahwa perlakuan pakan tidak berpengaruh terhadap produksi biomassa mikroba. Baik jerami jagung maupun silase jerami jagung mempunyai nilai produksi biomassa mikroba yang relatif sama. Hal ini dikarenakan jerami jagung dan silase jerami jagung mempunyai kandungan nutrien yang relatif sama pula. Hal ini sesuai dengan pendapat Puastuti (2009) yang menyatakan bahwa produksi biomassa mikroba dipengaruhi oleh nutrien pakan. Lebih lanjut dijelaskan bahwa apabila nutrien untuk mikroba rumen tercukupi, maka biomassa mikroba rumen akan meningkat sehingga daya cerna pakan juga akan meningkat. Selain itu nilai $\mathrm{pH}$ yang diperoleh dalam penelitian ini mencukupi untuk kebutuhan aktivitas dan pertumbuhan mikroba rumen, sehingga proses fermentasi oleh mikroba rumen (produksi VFA dan amonia) juga berlangsung dengan baik yang ditandai dengan nilai produksi VFA dan amonia berada pada kisaran mencukupi untuk kebutuhan mikroba rumen. Hal ini sesuai dengan pendapat Dehority (2004). Yang menyatakan bahwa salah satu yang mempengaruhi aktivitas dan pertumbuhan mikroba adalah nilai $\mathrm{pH}$.

\section{Kesimpulan}

Berdasarkan hasil penelitian dapat disimpulkan bahwa baik pakan perlakuan maupun waktu inkubasi tidak memberikan pengaruh yang nyata $(\mathrm{p}>0,05)$ terhadap nilai $\mathrm{pH}, \mathrm{VFA}, \mathrm{NH}_{3}$, produksi gas total dan produksi biomassa mikroba serta tidak terdapat interaksi antara perlakuan pakan dengan waktu inkubasi. Namun secara numerik kisaran $\mathrm{pH}$ perlakuan adalah 6,897,05; konsentrasi VFA sebesar 107-110 mM, konsentrasi amonia 23,92 - 29,88 mg/100 ml, produksi gas total sebesar 27,47 - 46,31 $\mathrm{ml} / 200 \mathrm{mg}$ dan produksi biomassa mikroba sebesar 40,60 - 56,80 mg/20 ml mencukupi kebutuhan ternak ruminansia sehingga baik jerami jagung maupun silase sinambung jerami jagung dapat digunakan sebagai pakan ternak karena mampu memenuhi kebutuhan nutrien ternak ruminansia ditinjau dari produksi gas dan fermentasi pakan dalam rumen secara in vitro.

\section{Daftar Pustaka}

Arora, S.P. (1995). Pencernaan Mikroba pada Ruminansia. Diterjemahkan oleh: Murwani, R. Gadjah Mada University Press, Yogyakarta.

Blummel, M., dan Orskov, E. R. 1993. Comparison ofIn Vitro Gas Production an Nylon Bag Degradability Roughages in Prediction of Feed Intake in Cattle. Animal feed science and technology, 40, 109-229.

Dehority, B.A. 2004. Rumen Microbiology. Nottingham University Press, Nottingham.

Delima, M., Karim, A., Yunus, M. (2015). Kajian Potensi Produksi Hijauan Pakan pada Lahan Eksisting dan Potensial untuk meningkatkan Populasi Ternak Ruminansia di Kabupaten Aceh Besar. Agripet, 15(1): 33-40

Hindratiningrum, N., Bata, M. dan Santosa, S.A. (2011). Produk Fermentasi Rumen dan Produksi Protein Mikroba Sapi Lokal yang diberi Pakan Jerami Amoniasi dan Beberapa Bahan Pakan Sumber Energi. Agripet, 11(2), 29-34.

Hungate, R.E. (1996). The Rumen and Its Microbes. Academic Press, New York.

Imanda, S., Effendi, Y., Sihono dan Sugoro, I. 2016. Evaluasi In Vitro Silase Sinambung Sorgum varietas samurai 2 yang mengandung probiotic BIOS K2 dalam cairan rumen kerbau. Jurnal Ilmiah Aplikasi Isotop Dan Radiasi. 12(1):1-12.

Krishnamoorthy, U. (2001). RCA trainng Workshop on In Vitro Techniques for Feed Evaluation. The International Atomic Energy Agency Vienna, Austria and Departement of Livestock Production Management, Veterinary College Univrsity of Agricultural Science. Bangalore: Italia.

Lutzhoft, H.C.H., Angelidaki, I., dan Boe, K. (2014). Comparison of VFA titration prosedures used for monitoring the biogas process. Water Research, (54) 262-272.

McDonald, P., Edward, R.A., Greenhalg, J.F.D., dan Morgan, C.A. (2002). Animal Nutrition. Ed ke-6. Imprint Pearson Education Prontice Hill, England. 
Menke, A., dan Steingass, A. (1998). Estimation of The Energetic Feed Value Obtained from Chemical Analysis and In vitro Gas Production Using Rumen Fluid. Anim. Res. Dev. 7- 55.

Nopitasari, S., Widiyastuti, T. dan Sutardi, T.R. (2013). Pengujian Kecernaan Bungkil Biji Jarak Fermentasi ditinjau dari Produksi VFA dan $\mathrm{NH}_{3}$ secara In Vitro. Jurnal Ilmiah Peternakan, 1(2), 446-454.

Nuswantara, L.K. (2002). Ilmu makanan ternak ruminansia. Semarang, fakultas peternakan, universitas diponegoro, 105106.

Orskov, E.R. dan Ryle, M. (1990). Energy Nutrition in Ruminants. Elsevier Sci. PUGI. Ltd. London, 25-50.

Pertiwi, B., Prasetiyono, B.W.H.E., dan Muktiani, A. (2015). Pengaruh pemberian total mixed ration berbasis jerami jagung teramoniasi terhadap pemanfaatan nitrogen pada sapi perah laktasi. Agromedia 33(1): 97-103.

Pratiwi, I., Fathul, F., dan Muhtarudin. (2015). Pengaruh penambahan berbagai starter pada pembuatan silase ransum terhadap kadar serat kasar, lemak kasar, kadar air dan bahan ekstrak tanpa nitrogen silase. Jurnal Ilmiah Peternakan Terpadu, 3(3):116-120.

Puastuti, W. (2009). Manipulasi Bioproses dalam Rumen untuk Meningkatkan Penggunaan Pakan Berserat. Wartazoa, 19(4), 180-190.

Rukana, Harahap, A.E., dan Fitra, D. (2014). Karakteristik fisik silase jerami jagung (Zea mays) dengan lama fermentasi dan level molases yang berbeda. jurnal peternakan 11(2): 64-68.Satter, L.D., dan Slyter, L.L. (1974). Effect of Ammonia Concentration of Rumen Microbial Protein Production In Vitro. Br J Nutr. 32(2), 199-208.

Sugoro, I.( 2010). Aplikasi Silase sinambung hijauan pakan ternak ruminansia di Nusa Penida Bali. Laporan Penelitian spesifik lokasi, RISTEK.

Sutardi, T. (2006). Landasan Ilmu Nutrisi Jilid I. Departemen Ilmu Makanan Ternak. Fakultas Peternakan. Institut Pertanian, Bogor.

Titterton, M., dan Bareeba, F.B. (2008). Grass and legume silages in the tropics, FAO electronic confrence on tropical silage. $1,1-16$

Van Soest, P.J. (1994). Nutritional Ecology of the Ruminant second edition. Cornell Univ. Press, Ithaca, NY.

Widodo, Wahyono, F., dan Sutrisno. (2012). Kecernaan bahan kering, kecernaan bahan organik, produksi VFA dan NH3 pakan komplit dengan level jerami padi secara In Vitro. J. Anmal Agriculture 1(1): 215-230

Yanuarianto, O., Amin, M., Ibal, M., dan Hasan, S.D. (2015). Kecernaan Bahan Kering dan Bahan Organik jerami padi yang difermentasi dengan kombinasi kapur tohot, Bacillus s., dan air kelapa pada waktu yang berbeda. Jurnal Ilmu Dan Teknologi Peternakan Indonesia 1(1), 47-52.

Sandi.S, E. Laconib, A. Sudarman, K.G. Wiryawan dan D. Mangundjaja. (2010). Kualitas Nutrisi Silase Berbahan Baku Singkong yang Diberi Enzim Cairan Rumen Sapi dan Leuconostoc mesenteroides. Media Peternakan. 33 (1): 25-30.

Saqifah, N., Purbowati, E., dan Rianto, E. (2010). Pengaruh Ampas Teh dalam Pakan Konsentrat terhadap Konsentrasi VFA dan Nh3 Cairan Rumen untuk Mendukung Pertumbuhan Sapi Peranakan Ongole. Prosiding Seminar Nasional Teknologi Peternakan dan Veteriner 2010: 205-210. 